\title{
Forum
}

\section{Recommendations for Development of Resilience-Based State-and-Transition Models}

\author{
D. D. Briske, ${ }^{1}$ B. T. Bestelmeyer, ${ }^{2}$ T. K. Stringham, ${ }^{3}$ and P. L. Shaver ${ }^{4}$ \\ Authors are ${ }^{1}$ Professor, Department of Ecosystem Science and Management, Texas AひM University, 2138 TAMU, College Station, TX 77843, USA; \\ ${ }^{2}$ Ecologist, USDA-ARS, Jornada Experimental Range and Jornada Basin LTER, MSC 3JER, Box 30003, New Mexico State University, Las Cruces, NM \\ 88003, USA; ${ }^{3}$ Associate Professor, Department of Animal Biotechnology, University of Nevada-Reno, Reno, NV 89557, USA; and ${ }^{4}$ Rangeland \\ Management Specialist, USDA-NRCS, West National Technology Support Center, 1201 NE Lloyd Blvd, Suite 100, Portland, OR 97232, USA.
}

\begin{abstract}
The objective of this paper is to recommend conceptual modifications for incorporation in state-and-transition models (STMs) to link this framework explicitly to the concept of ecological resilience. Ecological resilience describes the amount of change or disruption that is required to transform a system from being maintained by one set of mutually reinforcing processes and structures to a different set of processes and structures (e.g., an alternative stable state). In light of this concept, effective ecosystem management must focus on the adoption of management practices and policies that maintain or enhance ecological resilience to prevent stable states from exceeding thresholds. Resilience management does not exclusively focus on identifying thresholds per se, but rather on within-state dynamics that influence state vulnerability or proximity to thresholds. Resiliencebased ecosystem management provides greater opportunities to incorporate adaptive management than does threshold-based management because thresholds emphasize limits of state resilience, rather than conditions that determine the probability that these limits will be surpassed. In an effort to further promote resilience-based management, we recommend that the STM framework explicitly describe triggers, at-risk communities, feedback mechanisms, and restoration pathways and develop process-specific indicators that enable managers to identify at-risk plant communities and potential restoration pathways. Two STMs representing different ecological conditions and geographic locations are presented to illustrate the incorporation and application of these recommendations. We anticipate that these recommendations will enable STMs to capture additional ecological information and contribute to improved ecosystem management by focusing attention on the maintenance of state resilience in addition to the anticipation of thresholds. Adoption of these recommendations may promote valuable dialogue between researchers and ecosystem managers regarding the general nature of ecosystem dynamics.
\end{abstract}

\section{Resumen}

El objetivo de este documento es recomendar las modificaciones conceptuales para la incorporación en los modelos estado-ytransición (STMs) para ligar explícitamente este marco con el concepto de resistencia ecológica. La resistencia ecológica describe la cantidad de cambio o de interrupción que se requiere para transformar un sistema mantenido con sus procesos y estructuras mutuas a un sistema diferente (ej. un estado estable alternativo). Basándose en esta idea, el manejo eficaz del ecosistema debe centrarse en la adopción de prácticas de manejo y reglamentos que mantengan o promuevan la resistencia ecológica para evitar que los estados estables excedan los umbrales. El manejo de la resistencia no se centra exclusivamente en la identificación de umbrales por sí mismo, sino en las dinámicas dentro del-estado que influencian vulnerabilidad o proximidad del estado a los umbrales. El manejo del ecosistema basado en la resistencia proporciona mayores oportunidades de incorporar a un manejo adaptativo que el manejo basado en umbrales debido a que los umbrales acentúan los límites de resistencia del estado, en lugar de las condiciones que determinan la probabilidad de que estos límites sean sobrepasados. En un esfuerzo para promover aun más allá el manejo basado en la resistencia, recomendamos que el marco del STM describa explícitamente causas, comunidades en riesgo, mecanismos de regeneración y vías para la restauración y desarrollo de indicadores que permitan a los encargados identificar comunidades de plantas en riesgo y vías potenciales para su restauración. Dos STM que representan diversas condiciones ecológicas y localizaciones geográficas se presentan para ilustrar la incorporación y el uso de estas recomendaciones. Anticipamos que estas recomendaciones permitirán a STM capturar la información ecológica adicional y contribuir a un mejor manejo del ecosistema poniendo atención en el mantenimiento del estado de resistencia además de la anticipación de umbrales. La adopción de estas recomendaciones puede promover un valioso diálogo entre investigadores y encargados del los ecosistemas con respecto a la dinámica del ecosistema.

Key Words: alternative stable states, dynamic regimes, ecological resilience, rangeland monitoring, thresholds

\section{INTRODUCTION}

We gratefully acknowledge financial support from the NRCS to partially sponsor the STM Workshop from which many of these concepts emerged.

Manuscript review and final acceptance were conducted by the former Editor-in-Chief, M. K. Owens.

Correspondence: D. D. Briske, Dept of Ecosystem Science and Management, Texas A\&M University, 2138 TAMU, College Station, TX 77843, USA. Email: dbriske@tamu.edu

Manuscript received 24 May 2007; manuscript accepted 16 April 2008.
State-and-transition models (STMs) have been formally adopted for rangeland application by several federal agencies as a central component of Ecological Site Descriptions and are broadly used for ecosystem assessment within the rangeland profession (e.g., Chartier and Rostagno 2006). STMs are organized as a collection of alternative stable states that 


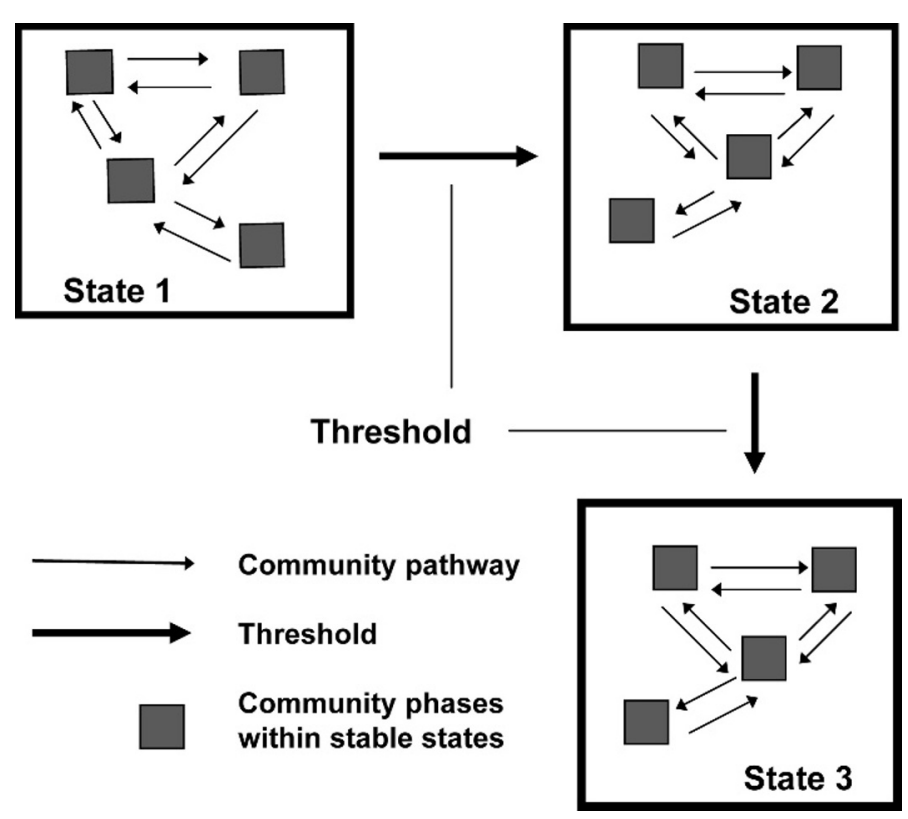

Figure 1. Illustration of a conventional state-and-transition model depicting three stable states (large open boxes) and four community phases (small solid boxes) within each state. This framework is used to describe known or anticipated pathways of vegetation dynamics on individual ecological sites. Transitions among community phases within states are reversible, but those between states are not reversible without management intervention (i.e., a threshold has been crossed). Both reversible and nonreversible state dynamics must be evaluated for accurate ecological assessments and management applications. Adapted from Stringham et al. (2003).

represent the known or anticipated ecosystems that individual ecological sites (soil/climate-based land units) may support (Westoby et al. 1989; Stringham et al. 2003). Each state contains one or more community phases representing system dynamics within the limits of the state. Dynamics among community phases may be driven independently or in combination by natural events (e.g., succession or disturbances) or human activities (e.g., land management and development; Walker et al. 2004). Individual states are separated by thresholds that can be induced by natural or human events (Fig. 1). STMs have been explicitly developed to evaluate ecosystem dynamics and establish management objectives on rangelands by accommodating multiple successional pathways and alternative stable states on individual ecological sites (Westoby et al. 1989; Bestelmeyer et al. 2003; Stringham et al. 2003; Bestelmeyer et al. 2004; Briske et al. 2005). Although less well recognized, STMs also provide a framework to assess the current and future resilience of ecosystems under specific sets of conditions, drivers, and disturbances (e.g., Walker et al. 2004; Allen et al. 2005; Cumming et al. 2005).

Our understanding of STMs has advanced substantially since formal definitions of model components were proposed (Westoby et al. 1989; Friedel 1991; Stringham et al. 2003). Additional complexity has been recognized in the form of triggers, structural patterns, and ecological functions that modify state dynamics and contribute to the crossing of thresholds and formation of alternative stable states (Briske et al. 2005, 2006; Bestelmeyer et al. 2006a; Peters et al. 2006a). A memorandum of understanding among three federal US agencies in 2005 calls for interagency adoption of the ecological site concept, providing further incentive for incorporation of current knowledge in the STM framework. This paper reports conceptual advancements in STMs that were developed and presented at a State-and-Transition Ecological Theory workshop sponsored by the US Department of Agriculture-Natural Resources Conservation Service (USDANRCS) and Oregon State University, August 2006.

The proposed conceptual modifications will provide three important benefits to the current STM framework. First, they explicitly connect the STM framework to the concept of ecological resilience (Briske et al. 2003; Folke et al. 2004; Cumming et al. 2005). This linkage increases relevance of the framework to a broader range of potential applications and stakeholders. Second, emphasis on resilience refocuses management attention toward state attributes and management actions that affect state vulnerability and proximity to thresholds, rather than on the identification of thresholds per se (Watson et al. 1996; Gunderson 2000). Third, they will provide the potential for STMs to capture a broader set of variables necessary to anticipate and identify conditions that determine state resilience. Current models often emphasize a narrow set of primarily management-related activities, including prescribed grazing and burning, to describe or anticipate thresholds (i.e., classification thresholds) and overlook the importance of interrelated ecological and management events contributing to ecosystem resilience (Bestelmeyer 2006). We argue here that the conceptual modifications described below strengthen both the ecological foundation and operational effectiveness of the STM framework.

\section{STMS ARE FOUNDED UPON ECOLOGICAL RESILIENCE}

The STM framework is founded upon the concept of ecological resilience, which originated from nonequilibrium theory during the 1970s (Holling 1973; Briske et al. 2003; Folke 2006; see Table 1). Ecological resilience describes the amount of change or disruption that is required to transform a system from being maintained by one set of mutually reinforcing processes and structures to a different set of processes and structures (Peterson et al. 1998). This interpretation of resilience assumes that ecosystems can be expressed as two or more alternative stable states and emphasizes the potential occurrence of state transitions based upon shifts between unique sets of organizing structures and processes (Fig. 2). This definition is distinct from that of engineering resilience, which describes the rate at which ecosystems return to their original stable state following a perturbation. This definition focuses on ecosystems that remain in a single stability domain or retain only a single equilibrium point. Thresholds represent conditions sufficient to modify ecosystem structure and function beyond the limits of ecological resilience, resulting in the formation of alternative states (e.g., Gunderson 2000; Scheffer et al. 2001; Stringham et al. 2003; Folke et al. 2004).

States represent a suite of plant community phases occurring on similar soils that interact with the environment to produce persistent functional and structural attributes and a character- 
Table 1. Resilience-based concepts recommended for incorporation in the state-and-transition model framework.

At-risk community phase_Plant community phase within a state that is most vulnerable to exceeding the resilience limits of the state (i.e., precarious; sensu Walker et al. 2004).

Ecological resilience-Amount of change or disruption that is required to transform a system from being maintained by one set of mutually reinforcing processes and structures to a different set of processes and structures.

Feedback mechanisms - Ecological processes that enhance (negative) or decrease (positive) ecosystem resilience.

Feedback switch-Point at which feedbacks shift from a dominance of negative feedbacks that maintain ecosystem resilience to a dominance of positive feedbacks that decrease ecosystem resilience and contribute to a state change.

Restoration pathways - Re-establishment of prethreshold states following active restoration of negative feedback mechanisms necessary to maintain the resilience of these states.

States - A suite of plant community phases occurring on similar soils that interact with the environment to produce persistent functional and structural attributes associated with a characteristic range of variability.

Thresholds - Conditions sufficient to modify ecosystem structure and function beyond the limits of ecological resilience, resulting in the formation of alternative states. Triggers - Biotic or abiotic variables or events, acting independently or in combination, that initiate threshold-related processes by contributing to the immediate loss of ecosystem resilience.

istic range of variability. Community phases represent withinstate variability that has also been described as dynamic regimes (Scheffer and Carpenter 2003). Some states express inherently high resilience (i.e., they are resistant; Walker et al. 2004) and have a low probability of approaching and crossing thresholds to form alternative stable states (i.e., shortgrass prairie, juniper, and mesquite woodlands; Fig. 2). Other states have inherently low resilience and must be carefully managed to minimize probabilities of crossing thresholds to alternative stable states (i.e., specific sites in desert grasslands, shrub steppe, mesic grasslands; Bestelmeyer et al. 2006b).

It should be noted that the depiction of resilience in Figure 2 applies only to two state systems separated by a threshold. If a third state is added to the right of State 2, the direction of resilience and feedbacks for State 2 will need to be reversed to

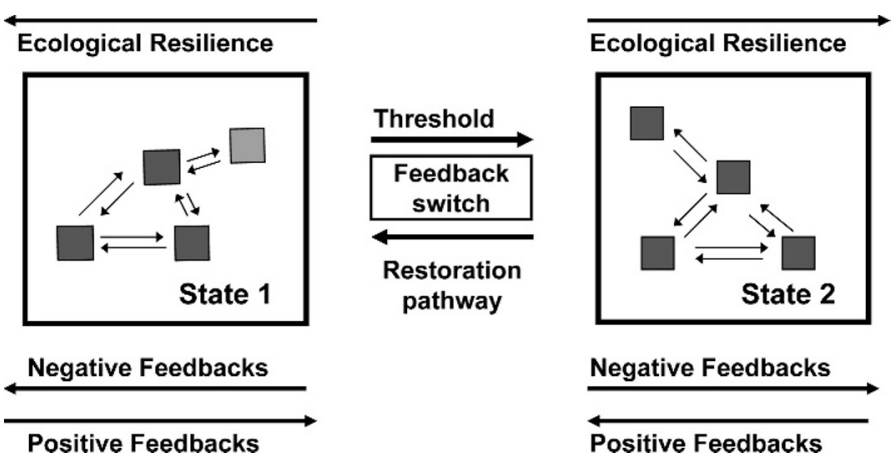

Figure 2. Ecological resilience can be envisioned as the movement of current and alternative states (large open boxes) toward or away from pending thresholds. State proximity to pending thresholds is dependent upon the resilience of various community phases (small solid boxes) that originate from the relative expression of negative:positive feedbacks. The at-risk community phase is represented by the lightly shaded box in State 1. An increase in negative feedbacks enhances resilience and moves community phases and associated states away from thresholds, whereas an increase in positive feedbacks diminishes resilience and moves community phases and states toward thresholds. States cross a threshold to an alternative state when there is a switch from a dominance of negative to positive feedbacks (e.g., feedback switch). Restoration pathways represent the reversal of thresholds by active restoration of negative feedback mechanisms. align properly with State 3. However, this does not detract from the application of these resilience-based concepts to STMs as indicated below.

Ecological resilience of desirable states can be reduced by improper land use practices (e.g., fire suppression, reduction of soil protection, and species introduction) and extreme environmental conditions (e.g., multiyear drought, intense storm events, insect and disease outbreaks), either independently or in combination (Folke et al. 2004; Cumming et al. 2005). Loss of resilience may often be expressed as a slow imperceptible decline over periods of years and decades that increases the probability of thresholds being crossed to form alternative stable states (Scheffer and Carpenter 2003). Alternatively, the loss of resilience may result from an abrupt change in ecosystem pattern and process induced by severe episodic events such as 500-yr storms or multiyear droughts that act on low-resilience systems (Beisner et al. 2003; Walker et al. 2004). We advocate that ecosystem management will be most effective if it focuses on the adoption of management practices and policies that maintain or enhance ecological resilience of desirable states, rather than solely seeking to avoid thresholds (e.g., Holling 1996).

The maintenance of state resilience and development of alternative states following the crossing of thresholds are directly related and represent opposite sides of the nonequilibrium coin. We are recommending that greater attention be directed toward resilience-based management because it emphasizes the conditions and dynamics that influence state proximity and vulnerability to potential thresholds, in addition to the thresholds themselves (e.g., Watson et al. 1996; Gunderson 2000; Allen et al. 2005). This important distinction increases the ability to manage ecosystem change rather than merely react to it by providing greater opportunities to incorporate adaptive management (Folke 2006). In other words, adaptive management can reduce the probability that thresholds will be crossed by maintaining state resilience without necessarily affecting the conditions that precipitate thresholds.

Resilience-based STMs are also applicable to rangeland ecosystems that currently exist in undesirable stable states. In these cases, the objective is to estimate the resilience attained by alternative states and the extent to which alternative states have moved beyond thresholds separating them from more desirable 
states. Application of this approach is described in the following section addressing restoration pathways.

\section{RESILIENCE-BASED CONCEPTS}

\section{At-Risk Plant Communities}

A critical management question drawing on resilience concepts (Table 1) is, "how far can ecosystems deviate from reference states (i.e., historic or potential plant community) before they are at risk of crossing a threshold" (Briske et al. 2006; Groffman et al. 2006)? This question may most effectively be addressed by identifying plant community phases within states that have undergone the greatest decrease in resilience. The "atrisk" plant community describes the community phase within a state that is most vulnerable to exceeding resilience limits of the state (i.e., precarious; sensu Walker et al. 2004). For example, particular patterns in vegetation and soil may provide evidence of vulnerable community phases, as well as the occurrence of triggers, to signal that management adjustments are required to avoid crossing a threshold (Bestelmeyer 2006; Tongway and Ludwig 1997). The at-risk community serves as an indicator of threshold risk for specific states and signals managers to take necessary actions to enhance state resilience.

Triggers represent biotic or abiotic variables or events, acting independently or in combination, that initiate threshold-related processes by contributing to the immediate loss of ecosystem resilience (Scheffer and Carpenter 2003; Briske et al. 2006). Triggers are ultimately responsible for inducing a feedback switch that alters ecosystem feedbacks from a dominance of negative feedbacks that maintain resilience to a dominance of positive feedbacks that decrease resilience and contribute to state change (Wilson and Agnew 1992; Folke et al. 2004). The switch from a dominance of negative to positive feedbacks represents the point at which ecological function ceases to support the former state and the system begins to reorganize into an alternative state. Development of alternative stable states following the occurrence of a feedback switch and the crossing of thresholds may be gradually expressed over several decades as resilience of alternative states continues to increase, but in other cases it may occur rapidly in conjunction with severe episodic events that impose substantial changes in state conditions (Beisner et al. 2003; Scheffer and Carpenter 2003; Walker et al. 2004). This implies that negative and positive feedbacks do not necessarily behave in a continuous and complementary manner within states. The rate at which the feedback switch is expressed will establish the degree of nonlinearity or discontinuity characteristic of specific thresholds (Briske et al. 2006). Recognition of the trigger-feedback concept partially explains why thresholds are so difficult to identify; they involve abrupt, short-term changes in ecological patterns and processes (e.g., occurrence of a feedback switch) that may have slowly developing, long-term consequences that are often difficult to recognize until the alternative state is well defined.

\section{Restoration Pathways}

The ability to return to previous states after thresholds have been crossed is also of vital interest to ecosystem managers. The re-establishment of prethreshold states following active restoration of negative feedback mechanisms necessary to maintain the resilience of these states can be described as restoration pathways. The concept of restoration pathways conveys that restoration practices are required before the former state can be recovered and it minimizes the inconsistency of suggesting that thresholds are reversible, which by definition they are not without management intervention. Restoration pathways vary greatly in probability of success, appropriateness of restoration prescriptions, and cost (Suding et al. 2004; Bestelmeyer 2006).

The answer to the question, "how resilient have alternative states become?" is dependent upon the extent to which negative feedbacks have developed in the alternative state and the extent to which biotic and abiotic components of the system have been modified. It is reasonable to assume that alternative states become more resilient with increasing modification of ecosystem structure and function after thresholds are exceeded. Feedback-driven change within a postthreshold state implies that restoration pathways become more difficult to implement over time (Whisenant 1999; Suding et al. 2004; Bestelmeyer 2006). Reestablishment of ecosystem function and resilience of the former state depends upon the extent of resilience attained by the alternative state and remaining residual properties of the former state (i.e., species composition, seed and soil properties) that promote restoration (Briske et al. 2006). This illustrates the need to identify indicators of potential restoration pathways that support development of appropriate and effective restoration prescriptions.

\section{Discontinuous Community Phases}

Community phases within a state are assumed to be readily reversible (i.e., double arrows between them) over relatively short time periods (e.g., years to decades) without management intervention, because they are not separated by thresholds (Stringham et al. 2003; Fig. 1). However, it has long been recognized that degradation and recovery within ecosystems may not necessarily progress through the same successional pathways, which represents the condition known as hysteresis (Walker 1993; Scheffer and Carpenter 2003). Hysteresis indicates that all community phases within a state may not have reversible connections because an intermediate phase may be required to recover specific community phases, even though the degradation pathway was more direct. For example, the atrisk community phase may not progress directly to the most resilient community phase from which it was transformed, without passing through an intermediate phase (i.e., the most and least resilient phases are discontinuous). Although this represents a rather subtle point, it may have important consequences for interpreting within-state dynamics, including both state proximity to thresholds and the appropriate restoration pathway in some ecosystems.

\section{DEVELOPMENT OF RESILIENCE ASSESSMENTS}

Assessment of state resilience represents an ecologically robust approach to ecosystem management, but it does not readily lend itself to application (Allen et al. 2005; Bennett et al. 2005; Groffman et al. 2006). Recognizable indicators and benchmark conditions are required to identify when states are approaching thresholds, as well as how far states have moved beyond 
Table 2. Summary of potential indicators and their corresponding assessment attributes to evaluate state vulnerability to thresholds and to assess potential restoration pathways.

\begin{tabular}{|c|c|c|}
\hline Category & Indicator & Assessment \\
\hline \multicolumn{3}{|c|}{ Indicators of state vulnerability to thresholds } \\
\hline \multirow[t]{6}{*}{ Triggers } & Severe drought & Weather records, plant cover, density, mortality \\
\hline & Series of wet years & Weather records, plant cover, density, establishment \\
\hline & Modified fire regimes & Land use history, woody plant density, fuel load, species composition \\
\hline & Severe grazing & Species composition, plant cover, size, density \\
\hline & Species introductions & Presence/absence, rate of spread, dominance \\
\hline & Episodic events & $\begin{array}{l}\text { Extreme weather patterns, marked change in species composition and cover, } \\
\text { soil movement and loss }\end{array}$ \\
\hline \multicolumn{3}{|l|}{ Feedbacks } \\
\hline \multirow[t]{6}{*}{ Soils } & Soil erosion/nutrient loss & Soil loss, rills, pedestals \\
\hline & Bare soil/patch size & Area, distribution, connectivity \\
\hline & Nutrient redistribution & Horizontal plant distribution, coppicing, desert pavement \\
\hline & Soil surface degradation & Aggregate stability, organic matter, microtopography \\
\hline & Soil compaction & Bulk density, strength \\
\hline & Aggregate stability & Soil surface slaking \\
\hline \multirow[t]{5}{*}{ Community } & Species/functional group loss & Species inventory/monitoring \\
\hline & Invasive species increases & Density, rate of spread, dominance \\
\hline & Vegetation spatial pattern & Cover, pattern, area, connectivity \\
\hline & Fine fuel load and continuity & Amount, pattern, area \\
\hline & Plant reproductive potential & Reproductive structures, plant size \\
\hline \multirow[t]{4}{*}{ Function } & Aboveground productivity & Biomass estimates \\
\hline & $\mathrm{C}$ and $\mathrm{N}$ pools & Biomass, soil organic matter \\
\hline & Infiltration rate & Plant, litter cover, slope, texture \\
\hline & Runoff rate and pattern & Plant, litter cover, slope, texture \\
\hline \multicolumn{3}{|c|}{ Indicators of potential restoration pathways } \\
\hline \multirow[t]{3}{*}{ Resilience of alternative state } & Species/functional group composition & Species composition, distribution \\
\hline & Soil modification & Depth, movement, loss, compaction layer \\
\hline & Hydrological function & Infiltration, channelization, runoff \\
\hline \multirow[t]{5}{*}{ Residual properties of former state } & Species composition & Density, distribution, size, reproduction \\
\hline & Seed sources & Availability, distribution \\
\hline & Hydrologic function & Infiltration, runoff \\
\hline & Nutrient distribution & Spatial plant and soil patterns \\
\hline & Soils & Horizons, depth, texture \\
\hline
\end{tabular}

thresholds after they have been crossed (Briske et al. 2006; see Bestelmeyer et al. 2006c and Sasaki et al. 2008 for examples; Fig. 2). Indicators of decreasing state resilience (e.g., increasing size and connectivity of bare patches) forewarn managers that actions must be taken to stabilize resilience and minimize the probability of crossing a threshold. Similarly, indicators of alternative state resilience (e.g., height and density of encroaching shrubs) following the crossing of thresholds provides information concerning both the probability and appropriate prescriptions for implementation of successful restoration pathways (Whisenant 1999; Bestelmeyer 2006; King and Hobbs 2006; Allen and Nowak 2008).

In order to operationalize resilience concepts, we recommend that the STM framework incorporate triggers, at-risk community phases, feedback mechanisms, and restoration pathways for each threshold separating individual states, including process-specific indicators, to identify at-risk plant communities and potential restoration pathways (Table 2). When the possibility exists for state conversion to more than one alternative state, information should be provided for each potential state. These new components can be explicitly described in both narrative and graphic form following the format of recently proposed changes in ecological site descriptions (see model examples below). Emphasis on resilience-based assessments requires that attention be focused toward development of process-based as well as structural indicators to interpret and describe both within- and betweenstate dynamics within the STM framework.

\section{Triggers and At-Risk Communities}

The description of triggers should include an assessment of important natural and anthropogenic events that are known or 
assumed to contribute directly to the loss of state resilience (Table 2). Some triggers may be anticipated in advance, but others are unpredictable and can only be recognized following their occurrence. Identification of at-risk communities involves the description of community phases known or assumed to have the least ecological resilience within a state (e.g., most likely to undergo soil loss or species invasion) and to immediately precede shifts to alternative states. Descriptions of triggers and at-risk communities should emphasize vegetation and soil indicators that are related to feedbacks and the processes that reduce resilience of existing states. See http://www.nm.nrcs.usda.gov/ technical/fotg/section-2/esd/sd2.html for early examples of indicator use in STMs.

\section{Positive and Negative Feedbacks}

Indicators of positive and negative feedbacks, contributing to either decreasing or increasing state resilience, respectively, are inferred from altered patterns and processes within individual states (Table 2). For example, if a large, continuous fine fuel load is an important negative feedback that maintains grasslands by frequent fires, then drought or excessive grazing for a prolonged period creates a strong positive feedback that moves the state toward a threshold by reducing fuel load, reducing fire frequency, and enabling woody plants to establish and develop. Increasing woody plant cover strengthens the positive feedback by further reducing the amount and continuity of fine fuel necessary to maintain a frequent fire regime. In semiarid regions, grassland states are maintained by a uniform distribution of soil nutrients, whereas shrub-land systems are promoted by the accumulation of nutrients within the immediate vicinity of isolated shrub canopies (Schlesinger et al. 1990). Consequently, redistribution of soils and nutrients from fine-grained to a coarse-grained scale represents a positive feedback with respect to grassland states, but a negative feedback with respect to the resilience of shrub-land states.

The approximate time period, either known or anticipated, required for triggers and feedbacks to reduce resilience and for alternative states to develop, should also be estimated. For example, we can estimate the number of years of fire suppression, in response to drought or severe grazing, beyond which fire is no longer carried effectively or able to induce mortality of established woody plants (see Swetnam et al. 1999 for related examples). In other cases, threshold conditions and alternative state development are not easily determined because they correspond to the frequency of episodic events such as high-intensity rainfall events, fire years, or multiyear drought.

\section{Resilience of Alternative States}

Patterns and processes associated with negative feedbacks in alternative states provide indicators of the resilience attained by these states after thresholds have been crossed. The occurrence of increasingly negative feedbacks within alternative states increases their resilience and diminishes the likelihood of restoration success. Increasing dominance of competitive plant species, soil modification, and alteration of surface hydrology are all important indicators of strengthening resilience of alternative states (Table 2). It is important to recognize that processes representing positive feedbacks (reducing resilience) in former states may constitute negative feedbacks (increasing resilience) in alternative states. For example, the reduction of fine fuel loads represents a positive feedback reducing resilience of grassland states, but it constitutes a negative feedback increasing resilience of woodland states.

\section{Restoration Pathways}

Restoration pathways are assessed with indicators that identify residual properties of former states that remain within alternative states after thresholds have been crossed (Briske et al. 2006). For example, when grassland states cross thresholds and are converted to woodland states not all properties (e.g., grassland species, seed banks, soils) of grassland states are immediately lost, even though resilience limits have been exceeded. The presence of residual ecosystem properties greatly influence the rate, probability of success, and prescriptions required for restoration pathways. These residual properties often decline with time following the crossing of thresholds and with increasing resilience of alternative states (e.g., Dye et al. 1995; Valone et al. 2002; Allen and Nowak 2008). The occurrence of residual properties may show spatially explicit patterns in heterogeneous landscapes that must be recognized and incorporated into restoration procedures (Peters et al. 2006b). Once these residual ecological properties have been lost, the probability of implementing successful restoration pathways diminishes and the potential cost of restoration increases (Briske et al. 2006; Bestelmeyer 2006). For example, seeding can overcome species loss in many cases, but repair of soil properties and hydrological processes may often require more elaborate and prolonged restoration prescriptions (Whisenant 1999; Herrick et al. 2006). However, these residual properties must be interpreted with caution, because their mere presence does not necessarily ensure the existence of viable restoration pathways, especially if other site characteristics have been substantially modified (e.g., altered hydrological characteristics, redistribution of soil and nutrients).

Community phases within alternative states that have developed the least resilience (e.g., fewest negative feedbacks) and possess the greatest proportion of residual properties of the former state are the most likely candidates from which to initiate restoration pathways. However, successful restoration pathways may not necessarily involve the same community phases that existed when thresholds were crossed because of potential hysteresis effects described in the previous section on discontinuous community phases. The potential for unique thresholds and restoration pathways (i.e., loss and recovery of state resilience) is strongly influenced by the extent to which the structure and function of alternative states has deviated from that of former states.

\section{APPLICATION OF RESILIENCE- BASED RECOMMODATIONS}

Two STMs are presented to illustrate how these recommended modifications could be applied in the context of the USDANRCS STM format developed for inclusion in ecological site descriptions. Each example features distinct processes underly- 


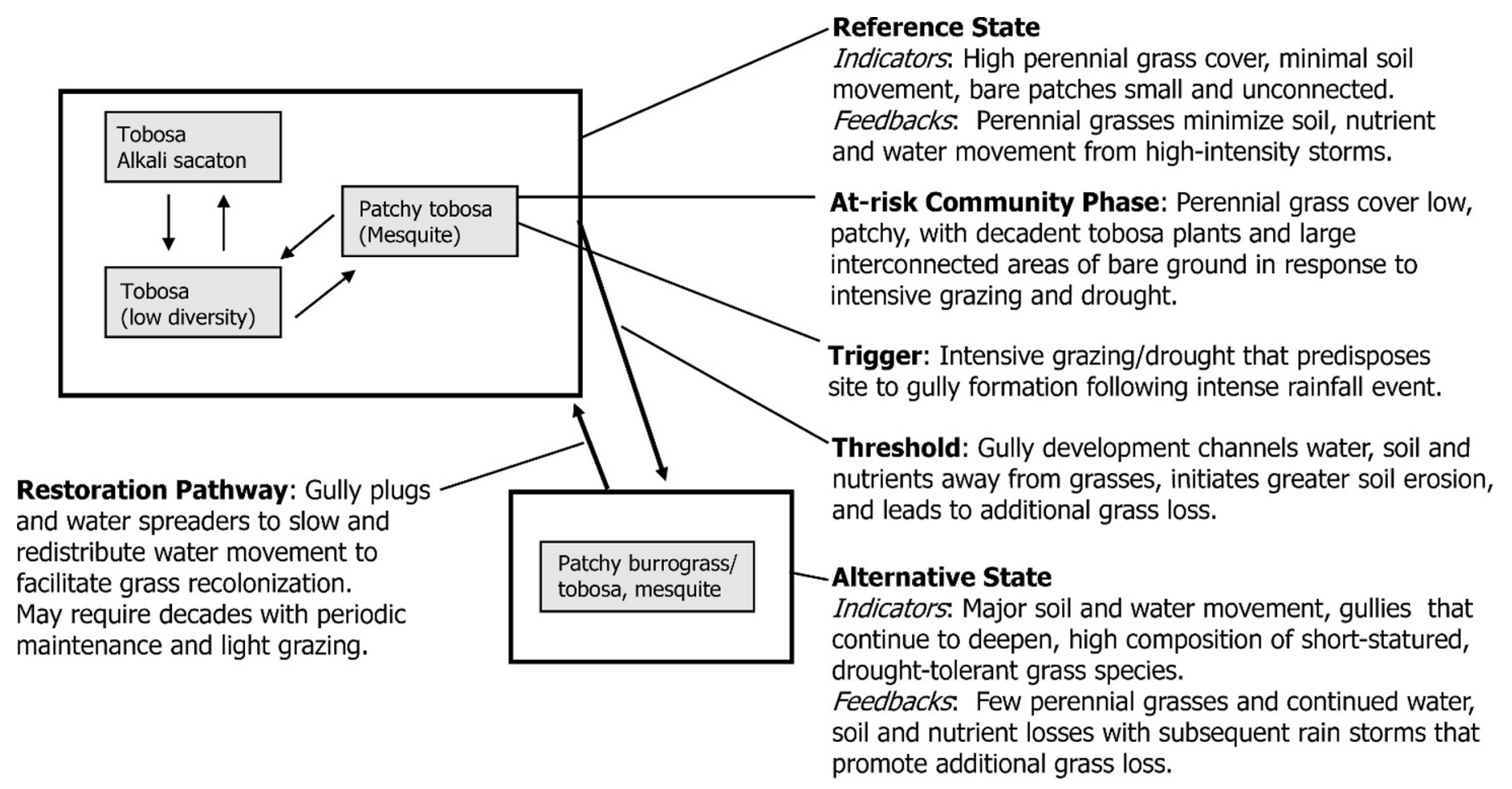

Figure 3. A partial model and interpretive text from the Draw ecological site in the northern Chihuahuan Desert of southwestern New Mexico (Major Land Resource Area 42B, 20-25-cm precipitation zone). Species presented in the model include tobosa (Pleuraphis mutica Buck.), alkali sacaton (Sporobolus airoides [Torr.] Torr.), burrograss (Scleropogon brevifolius Phil.), and mesquite (Prosopis glandulosa Torr.).

ing unique state dynamics and threshold behaviors to illustrate the robust application of these proposed modifications. The examples specifically identify where the concepts of "at-risk community phases," "feedbacks," "triggers," "restoration pathways," and their related indicators are included as specific components of model diagrams and narrative.

The first example describes a hydrology-based threshold in the Draw ecological site in the northern Chihuahuan Desert of southwestern New Mexico (Major Land Resource Area [MLRA] 42B, 20-25-cm precipitation zone; Fig. 3). This example conveys the development of an at-risk community defined by increased vulnerability to catastrophic erosion. The transition to a gullied state is triggered by a high-intensity rainfall event affecting a community phase characterized by low grass cover and large patches of bare soil. The threshold is defined when formation of gullies initiates self-reinforcing degradation (e.g., negative feedback for maintenance of the gullied state), even with improved grazing management. Deepening of the gully causes increasing resilience of the post-threshold state. Restoration pathways initially involve gully repair to halt and potentially reverse degradation. Larger gullies associated with soil loss adjacent to the channel are more difficult to restore.

The second example demonstrates the effect of fire on woody plant invasion in the Mountain Clayey ecological site in the Upper Snake River area of eastern Oregon and western Idaho (MLRA 10, 30.5-40.5-cm precipitation zone; Fig. 4). Drought and intensive grazing trigger reduced fuel loads and fire frequency (e.g., positive feedbacks) to allow western juniper (Juniperus occidentalis Hook.) to establish and attain a sufficient height and density to minimize fire-induced mortality (e.g., the threshold). As the juniper woodland matures and herbaceous species decline, infiltration rates decrease and overland flow increases to establish a negative feedback that promotes resilience of the woodland state (Petersen and Stringham 2008). A restoration pathway to mountain big sagebrush (Artemisia tridentata subsp. vaseyana [Rydb.] Beetle) steppe is possible on sites with intact soils via mechanical juniper removal, but seeding of native grasses and sagebrush may be required if seed pools are limited.

\section{MANAGEMENT IMPLICATIONS}

We suggest that incorporation of more explicit resilience-based concepts within the STM framework accomplishes two important objectives. First, the concepts expand the ecological foundation of the STM framework by directly linking it to ecological resilience. Adoption of resilience concepts promotes adaptive management by emphasizing indicators of state resilience in addition to indicators of pending thresholds. Second, the recommended modifications enable STMs to identify a broader range of variables to anticipate and identify conditions that determine state resilience to better inform ecosystem managers of risk and restoration options. We anticipate that incorporation of resilience-based concepts will enhance the capacity of the STM framework to capture and convey ecological information to a broader group of stakeholders to promote dialogue between researchers and ecosystem managers. 


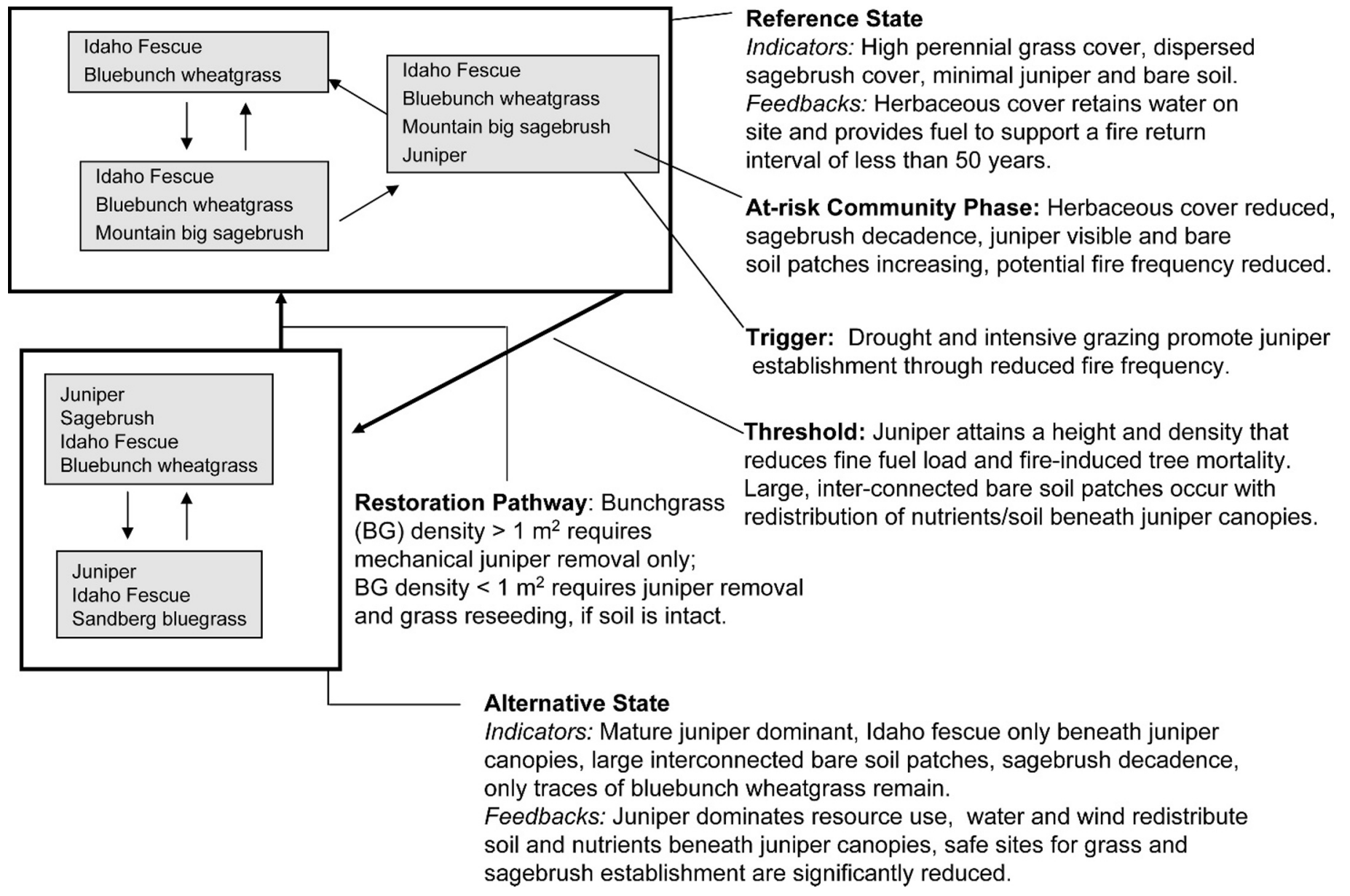

Figure 4. A model and interpretive text from the Mountain Clayey ecological site in the Upper Snake River area of eastern Oregon and western Idaho (Major Land Resource Area 10, 30-40-cm precipitation zone). Species presented in the model include bluebunch wheatgrass (Pseudoroegneria spicata [Pursh] A. Love), Idaho fescue (Festuca idahoensis Elmer), western juniper (Juniperus occidentalis Hook.), mountain big sagebrush (Artemisia tridentata Nutt. subsp. vaseyana [Rydb.] Beetle), and Sandberg bluegrass (Poa secunda J. Presl).

\section{ACKNOWLEDGMENTS}

The authors wish to thank two anonymous reviewers, Brian Walker, and the associate editor Robert Nowak for insightful comments that improved the manuscript.

\section{LITERATURE CITED}

Allen, C. R., L. Gunderson, and A. R. Johnson. 2005. The use of discontinuities and functional groups to assess relative resilience in complex systems. Ecosystems 8:958-966.

Allen, E. A., And R. S. Nowak. 2008. Effects of pinyon-juniper tree cover on soil seed bank. Rangeland Ecology and Management 61:63-73.

Beisner, B. E., D. T. Haydon, and K. Cuddington. 2003. Alternative stable states in ecology. Frontiers in Ecology and the Environment 1:376-382.

Bennett, E. M., G. S. Cumming, and G. D. Peterson. 2005. A systems model approach to determining resilience surrogates for case studies. Ecosystems 8:945-957.

Bestelmeyer, B. T. 2006. Threshold concepts and their use in rangeland management and restoration: the good, the bad, and the insidious. Restoration Ecology 14:325-329.

Bestelmeyer, B. T., J. R. Brown, K. M. Havstad, R. Alexander, G. Chavez, and J. E. HerRick. 2003. Development and use of state-and-transition models for rangelands. Journal of Range Management 56:114-126.

Bestelmeyer, B. T., J. E. Herrick, J. R. Brown, D. A. Trujlllo, and K. M. Havstad. 2004. Land management in the American southwest: a state-and-transition approach to ecosystem complexity. Environmental Management 34:38-51.
Bestelmeyer, B. T., D. A. Trujillo, A. J. Tugel, and K. M. Havstad. 2006a. A multiscale classification of vegetation dynamics in arid lands: what is the right scale for models, monitoring, and restoration? Journal of Arid Environments 65:296-318.

Bestelmeyer, B. T., J. P. Ward, and K. M. Havstad. 2006b. Soil-geomorphic heterogeneity governs patchy vegetation dynamics at an arid ecotone. Ecology 87:963-973

Bestelmeyer, B., J. Ward, J. Herrick, and A. Tugel. 2006c. Fragmentation effects on soil aggregate stability in a patchy arid grassland. Rangeland Ecology and Management 59:406-415.

Briske, D. D., S. D. Fuhlendorf, and F. E. Smeins. 2003. Vegetation dynamics on rangelands: a critique of the current paradigms. Journal of Applied Ecology 40:601-614.

Briske, D. D., S. D. Fuhlendorf, and F. E. Smeins. 2005. State-and-transition models, thresholds, and rangeland health: a synthesis of ecological concepts and perspectives. Rangeland Ecology and Management 58:1-10.

Briske, D. D., S. D. Funlendorf, and F. E. Smeins. 2006. A unified framework for assessment and application of ecological thresholds. Rangeland Ecology and Management 59:225-236.

Chartier, M. P., and C. M. Rostagno. 2006. Soil erosion thresholds and alternative states in northeastern Patagonian rangelands. Rangeland Ecology and Management 59:616-624.

Cumming, G. S., G. Barnes, S. Perz, M. Schmink, K. E. Sieving, J. Southworth, M. Binford, R. D. Holt, C. Stickler, and T. Van Holt. 2005. An exploratory framework for the empirical measurement of resilience. Ecosystems 8:975-987. 
Dye, K. L., D. N. Ueckert, And S. G. Whisenant. 1995. Redberry-juniper-herbaceous understory interactions. Journal of Range Management 48:100-107.

FoLKE, C. 2006. Resilience: the emergence of a perspective for social-ecological systems analyses. Global Environmental Change 16:253-267.

Folke, C., S. Carpenter, B. Walker, M. Scheffer, T. Elmovist, L. Gunderson, and C. S. Holuing. 2004. Regime shifts, resilience, and biodiversity in ecosystem management. Annual Review of Ecology, Evolution and Systematics 35:557581.

FRIEDEL, M. H. 1991. Range condition assessment and the concept of thresholds: a viewpoint. Journal of Range Management 44:422-426.

Groffman, P. M., J. S. Baron, T. Blett, A. J. Gold, I. Goodman, L. H. Gunderson, B. M. Levinson, M. A. Palmer, H. W. Paerl, G. D. Peterson, N. L. Poff, D. W. Rejeski, J. F. Reynolds, M. G. Turner, K. C. Weathers, and J. Wiens. 2006. Ecological thresholds: the key to successful environmental management or an important concept with no practical application? Ecosystems 9:1-13.

Gunderson, L. H. 2000. Ecological resilience-in theory and application. Annual Review of Ecology and Systematics 31:425-439.

Herrick, J. E., K. M. Havstad, and A. Rango. 2006. Remediation research at the Jornada: Past and future. In: K. M. Havstad, W. H. Schlesinger, and L. F. Huenneke [EDS.]. Structure and function of a Chihuahuan desert ecosystem: the Jornada Basin LTER. Oxford, United Kingdom: Oxford University Press. p. 278-304.

Holuıng, C. S. 1973. Resilience and stability of ecological systems. Annual Review of Ecology and Systematics 4:1-23.

Holııng, C. S. 1996. Surprise for science, resilience for ecosystems, and incentives for people. Ecological Applications 6:733-735.

KING, E. G., AND R. J. HoBBS. 2006. Identifying linkages among conceptual models of ecosystem degradation and restoration: towards an integrative framework. Restoration Ecology 14:369-378.

Peters, D. P., B. T. Bestelmeyer, E. L. Fredrickson, J. E. Herrick, H. C. Monger, and K. M. Havstad. 2006a. Disentangling complex landscapes: new insights to forecasting arid and semiarid system dynamics. Bioscience 56:491-501.

Peters, D. P. C., I. Mariotto, K. M. Havstad, and L. W. Murray. 2006b. Spatial variation in remnant grasses after a grassland-to-shrubland state change: implications for restoration. Rangeland Ecology and Management 59:343-350.

Petersen, S. L., and T. K. Stringham. 2008. Infiltration, runoff, and sediment yield in response to Western juniper encroachment in southeast Oregon. Rangeland Ecology and Management 61:74-81.

Peterson, G., C. R. Allen, and C. S. Holling. 1998. Ecological resilience, biodiversity, and scale. Ecosystems 1:6-18.
Sasaki, T., T. Okayasu, U. Jamsran, and K. Takeuchi. 2008. Threshold changes in vegetation along a grazing gradient in Mongolian rangelands. Journal of Ecology 96:145-154.

Scheffer, M., and S. Carpenter. 2003. Catastrophic regime shifts in ecosystems: linking theory to observation. Trends in Ecology and Evolution 18:648-656.

Scheffer, M., S. Carpenter, J. A. Foley, C. Folke, and B. Walker. 2001. Catastrophic shifts in ecosystems. Nature 413:591-596.

Schlesinger, W. H., J. F. Reynolds, G. L. Cunningham, L. F. Huenneke, W. M. Jarrell, R. A. Virginia, AND W. G. Whitford. 1990. Biological feedbacks in global desertification. Science 247:1043-1048.

Stringham, T. K., W. C. Krueger, and P. L. Shaver. 2003. State and transition modeling: an ecological process approach. Journal of Range Management $56: 106-113$.

Suding, K. N., K. L. Gross, and G. R. Houseman. 2004. Alternative states and positive feedbacks in restoration ecology. Trends in Ecology and Evolution 19:46-53.

Swetnam, T. W., C. D. Allen, and J. L. Betancourt. 1999. Applied historical ecology: using the past to manage the future. Ecological Applications 9:1189-1206.

Tongway, D. J., AND J. A. LudWIG. 1997. The nature of landscape dysfunction in rangelands. In: J. Ludwig, D. Tongway, D. Freudenberger, J. Noble, and K. Hodgkinson [EDS.]. Landscape ecology: function and management: principles from Australia's rangelands. Collingwood, Australia: CSIRO Publishing. p. 49-62.

Valone, T. J., M. Meyer, J. H. Brown, and R. M. Chew. 2002. Timescale of perennial grass recovery in desertified arid grasslands following livestock removal. Conservation Biology 16:995-1002.

Walker, B., C. S. Holling, S. R. Carpenter, and A. Kinzig. 2004. Resilience, adaptability and transformability in social-ecological systems. Ecology and Society 9:5. Available at: http//www.ecologyandsociety.org/vol9/iss2/art5. Accessed June 2005.

WALKER, B. H. 1993. Rangeland ecology: understanding and managing change. Ambio 22:80-87.

Watson, I. W., D. G. Burnside, and A. Mcr. Holm. 1996. Event-driven or continuous: which is the better model for managers? Rangeland Journal 18:351-369.

Westoby, M., B. H. Walker, and I. Noy-Meir. 1989. Opportunistic management for rangelands not at equilibrium. Journal of Range Management 42:266-274.

WhISENANT, S. G. 1999. Repairing damaged wildlands: a process-oriented, landscape-scale approach. New York, NY, USA: Cambridge University Press. $312 \mathrm{p}$.

Wilson, J. B., And A. D. Q. Agnew. 1992. Positive-negative feedback switches in plant communities. Advances in Ecological Research 23:263-336. 